\title{
Editorial
}

Jason W. Alvis*, Michael Staudigl, Olga Louchakova-Schwartz

\section{Faith in a Crisis: What Theological and Phenomenological Resources can Teach us in the COVID-19 Pandemic}

https://doi.org/10.1515/opth-2020-0187

received November 15, 2021

During the COVID 19-crisis we have witnessed religious authorities do and say things that past generations would have deemed unthinkable: Some have claimed that "there is no pandemic," urging their communities to break laws that temporarily prohibit them from large social gatherings. Others have committed acts of irruptive violence, even expressing pride in physically assaulting protesters. ${ }^{1}$ Yet simultaneously, we also have witnessed State authorities often overreach in their attempts to claim, hold, and order power during a state of emergency, with actions ranging from fear-mongering and horror, to biopolitical acceptance of how the virus attacks the weakest and most vulnerable among us.

These recent actions by religious authorities, and the more public, State-ordered responses, merely serve to illustrate how - during the COVID-19 crisis - the vexed relationships between religiosity and discursive reason, and between intuition and instrumental rationality, have become even more complicated. Given resurgent appeals to the transformative, purifying, redemptive, hopeful, and liberating force of religious resources in times of crisis, but also the negative socialities that might be attributed to one's faith commitments in forms of manipulation, new descriptions of the lived experiences and involved aspects of (ir)rationality as it relates to religiosity on societal, communal, and individual levels are necessary. Especially in the COVID-19 crisis, we need careful descriptions of:

- how to live through the everyday challenges presented by a pandemic such as this, and which resources (especially faith-based) we might draw upon in order to respond to (and cope with) these new challenges of irrationality that have arisen so often in conjunction with religious beliefs.

- what the staggering death-toll among industrial, so-called "first world" countries might teach us about the status of knowledge vis-à-vis affectivity; of the dialectics between individual, autonomous moral agents, and dominant power networks.

- the potentially long-lasting negative consequences for faith communities due to their temporary "forsaking of assembly" in solidarity with their ecclesial communities and in the name of a broader, perhaps even more "secular" social solidarity during this pandemic.

Such descriptions would yield a host of further questions. Does "reason" in fact hold the "force of law" over the faithful? What might the emotions of protest illuminate about representation, embodiment, and

1 See https://www.christianpost.com/news/john-macarthur-urges-churches-to-challenge-govt-and-reopen-in-pandemic-andystanley-disagrees.html and https://religionnews.com/2020/09/01/eric-metaxas-protester-menaced-punch-video-trump-rnc/.

\footnotetext{
* Corresponding author: Jason W. Alvis, Department of Philosophy, University of Vienna, Vienna, Austria, e-mail: jason.wesley.alvis@univie.ac.at

Michael Staudigl: Department of Philosophy, University of Vienna, Vienna, Austria, e-mail: michael.staudigl@univie.ac.at Olga Louchakova-Schwartz: University of California Davis, Department of Public Health Sciences and School of Medicine, Davis, United States of America, e-mail: olouchakova@gmail.com
} 
interpersonal trust? Are we witnessing faith communities' outsourcing of their virtue to the State in any way during this crisis, a crisis in which the "relevance" of responding to the pandemic "imposes" itself upon our rationality, interrupting our subjective mastery of everyday life? Has the COVID-19 crisis given rise to a deeper symptom or manifestation of our irrational misinterpretation of how we believe God has called for human "dominion" over our planet's resources in this age of the anthropocene? And finally, in what ways might our responses to the present crisis demonstrate a growing, "secular" arrogance that has allowed us to believe we have successfully purged all elements of faith and religiosity from our socio-political forms of life and thought?

This special issue is dedicated to interpreting such questions and describing such concepts phenomenologically, especially as they help illuminate the relationships between (ir)rationality and religiosity during this pandemic. We do not by any means claim that faith and religiosity are necessarily either irrational or rational, or that religion alone or reason alone hold responsibility for our present crises. Nor do we subscribe to the idea that any one-sided, so-called "secular reason" or "religious rationality" is any such "solution" to the troubles we face in this pandemic. Yet we do venture the hypothesis that this pandemic has worsened due to what it has induced to bubble to the surface of society: both some apparent lapses in judgement in our secular reason in regards to our beloved individualist ontologies of order (especially of freedom), and some discontents that have appeared in our religious communities that believe ecclesial belonging and social participation should take precedence over broader public health concerns within our towns and communities. This conflict has raised again the age-old question of the revolutionary principle of struggle in the Ecclesia Militans, not simply against invisible principalities of evil, but against political structures and decision makers that they believe oppress their religious expressions.

Given the astounding denials of trivial ontic-empirical-scientific facts on epidemics, and the gripping realities of global misinformation and the spread of conspiracy theories, the relationships between reason as manifested in politics, press, local decision-making - and the subjective dimension of faith - as manifested in worship gatherings, prayer, calls for religious freedom - are standing-out in a new light. We think that phenomenological reflection on religious experience (which often is far more reasonable than we tend to give it credit) and rationality (which harbours its own extra-rationality more than we would prefer to recognize) during this new situation of the COVID-19 pandemic calls for an immediate response.

\section{Phenomenology and (ir)rationality}

Since its inception, phenomenology has struggled with how it might square its enlightenment heritage and modern rationality with its acceptance of different kinds of individual, subjective, and even "perspectival" knowledge. Husserl's philosophical journey demonstrates this strain quite well. The Crisis of European Sciences seems unapologetically pro-enlightenment, but in a way many would not expect: he critiques the enlightenment-oriented "scientists" for their unquestioning acceptance of how the world somehow "exists." These natural scientists, a so-called "community of reason," remain in the dogmatic and absolutistic "natural attitude" insofar as they presumed that a "worldly positing of consciousness" immediately would yield a grasp of human essence. Contrary to these scientists, and in agreement with the contextualism of Landgrebe that there is no such thing as a neutral "pre-worldly state," Husserl held that the world is always "pre-given," and it thus becomes necessary for us to peel back the layers on how we are alwaysalready living-in-belief (Glaubensleben). Belief is a fundamental act that helps us along the path to reason.

At the height of his career, research in the humanities were still reeling from their romantic, at times transcendental search for the drives (irrational and rational) motivating us in psychological "behaviourism" (such as that of Brentano's descriptive psychology which described a priori mental acts in intentionality). And Husserl's development of momentary "suspensions" or bracketing of our convictions was to remedy this problem of the humanities and to initiate a kind of spiritual retrieval of the human sense of purpose, which, despite its claim to pragmatic reason, was far too clouded by its own interests, thereby negating its very pragmatic character. Husserl wanted therefore to study what we must take for granted; 
that which is so "obvious" (Selbstverständlich) that it ends up getting overlooked because we too hastily reach conclusions about the things in this pre-given lifeworld before examining them properly or imagining them differently.

In the predominant modern outlook, reason had been quite cunning and useful, and was in fact capable of accomplishing a number of fascinating achievements. But it has perhaps flown too close to the sun. The attempts to employ calculative rationality to develop controlled environments to the point that human behaviours are predictable ultimately backfires: As demonstrated by Derrida's metaphor of the shipwreck, modern reason at points encounters extra-rational ruptures that leads reason to "run aground" as it overextends itself. And when reason runs aground we are left with a busted ship, some kind of irrational rationality - as calculative reason seeks to remove the human element from its research, the personality and diversity of viewpoints of ratio begin to diminish. And this is where it leads to a kind of irrationality, as this dehumanization releases the individual and community from engaging in this ratio, resulting in the minimization of moral responsibility. This irrational rationality is rational insofar as it depersonalizes all factors such as emotion or affect that would derail it from achieving the goal of comprehensiveness. Yet it is precisely due to this kind of depersonalizing rationality that it manifests an irrationality, alienating the logic from the human person, ultimately even contributing negatively to the creation of spaces of "bare life" and "biopolitics" - of mere human survival.

\section{Contributions}

We are convinced that research that considers the interrelations between theology and phenomenology are uniquely suited not only to describe such "irrational rationality" but also ways to deal with it, especially as new expressions of irrationality are arising in the COVID-19 era. Each of the articles in this special issue contributes a unique perspective, argument, and interpretation of the problems and questions posed above concerning irrationality and faith during the COVID-19 pandemic. The seven articles in this collection are compiled into three sections: "Reasons for, and Critiques of, Irrationality in the pandemic," "Responses to, and Faith resources for, coping with the pandemic," and "Rethinking theology and belonging in the pandemic."

\section{Section 1: Reasons for, and Critiques of, Irrationality in the Pandemic}

In the first section, we investigate phenomenologically some of the theo-political and socio-cultural roots of our epistemic failures during the COVID-19 pandemic. Michael D. Barber's "The Twin Crises of Covid-19 and Racism: Pragmatic Mastery, Theory, Religion, and Ethics” relies especially upon Schutz and Levinas to develop the argument for how the present crisis is uniquely intertwined with another crisis - that of racism. Especially in the United States, racism and the polarization/relativization of knowledge that has contributed to the further spread of COVID-19 both share a common feature: what Barber calls the pursuit of "everyday pragmatic mastery beyond its legitimate boundary." Such pursuits have made even discourse and debate (those holy elements of democratic life) merely tools for gaining such mastery today, making us more likely to turn a blind eye to vilification and racism. And this instrumentality has given birth to the disastrous consequences of $(\mathrm{A})$ undercutting the possibility of being well-informed citizens who can reflect upon what our cultures "impose" upon us as "relevant"; and (B) blinding us to how we so often violently transgress ethical boundaries without taking others into consideration. And here the marginalization of religion and the theoretical reflection it champions plays an important role. In our instrumentalization of discourse and our lack of properly "bracketing" what our cultures impose upon us as important and "relevant," we lose sight of the non-pragmatic "provinces of meaning" that are essential to making us human - theoretical reflection and religiosity. 
James Mensch's "Subjectivity in the Age of Pandemics" studies some of the religious underpinnings of another kind of intertwining - that of the COVID-19 crisis and the climate crisis. Were it not for the uncontrollable will for human expansion, the over-expenditure of fossil fuels, and the general obsession with the "use value" of the earth, it is not simply that the COVID-19 crisis never would have expanded in the ways that it has, but rather that humans would have developed smarter ways to cooperate with other persons in this crisis. This marks the present "crisis of subjectivity" at the root of both crises, one that has a theological genealogy in the utter misunderstanding of the Biblical mandate of Imago Dei to have "dominion" over the earth. Using Levinas, among other scholars, to imagine theological subjectivity differently, one claim is that we are to take more seriously the "paradox of infinity," which entails that God hospitably opens up towards other creatures and is not simply withdrawn or closed in upon Godself. This should lead us to develop a new understanding of human subjectivity - one that reimagines the human's relation to the earth, not as an arbitrary object whose resources are to be extracted, but as a space that co-orients our subjectivities, and helps us treat other persons not as mere means to our gaining power.

Then in Guillermo Andrés Duque Silva and Cristina Del Prado Higuera's "Political Theology and COVID19: Agamben's Critique of Science as a New 'Pandemic Religion'," we see a different kind of argument emerge. By analysing both Agamben's controversial responses to States' handling of COVID-19 (ranging from depictions of COVID-19 as "just another flu" or a mere "invention" by the State) as well as his poignant theo-political insights, we are afforded new ways to critique the commonalities of irrationality and powerobsession. The authors reveal how Agamben's critique of States' horrifying claims that we are responsible for killing "our neighbours" helps us recognize more clearly the theological guises States use in employing various strategies of exercising "biopolitical power," especially today. In the current crisis, we are afforded the opportunity to see, right before our eyes, the speed at which corrupt political actors seek to establish a permanent "state of exception," one in which traditional sources of faith are being meticulously marginalized. For years now, the medical sciences have been developing into a new, secularized, form of religious experiencing and faith. And despite how we recently have witnessed resurgence of the need for religious faith and community, the State has undermined the Church, seeking to show that the Church has no power to satisfy the deep human needs faith traditionally has met. Instead, the State's present faith in scientific discovery - a "conspiracy of white coats" - often is presented as our only hope. This is a much deeper crisis, claim the authors, than the very COVID-19 pandemic in which we are living.

\section{Section 2: Responses to, and Faith Resources for, Coping with the Pandemic}

In the second section of articles, we shift from looking at the reasons for irrationality in the current pandemic to developing more constructive proposals for how to respond in particular to our irrational responses to the pandemic. Mirela Oliva's "How to Reasonably Wait for the End of the World: Aquinas and Heidegger on the Letters to the Thessalonians" helps build this bridge from critique to constructive proposal. The article argues for ways that Christians, in particular, can develop not just a "correct" theological eschatology, but also a helpful human attitude for dealing with real-life crisis scenarios. To accomplish this task, Oliva turns to a few thinkers whose work stands out in their reliance upon, and interpretation of, St. Paul's letters to the Thessalonians, letters written to those dealing with crisis and tribulation, and in need of embracing an entire transformation of understanding time as irruptive, as kairos. One way in which contemporary Western societies have dealt with crisis is a "calculative reasoning" that struggles to predict certain outcomes and fights against the sources of the pandemic, whereas another way has been to "wait" patiently and to develop a sober, Eckhartian Gelassenheit that lets go of a sense of control over all circumstances, while also finding ways to act, but not overreact. By juxtaposing our Western responses to the current pandemic to the crises of the early Christians in Thessalonica to whom Paul "proclaimed" the parousia in his letters, striking similarities of irrationality and inauthenticity arise - unpreparedness, 
downplaying the severity, utter panic, and the political instrumentalization of the crisis. Today what is needed is a constructive way of waiting actively.

Emil Salim's "Navigating the Stay-at-Home Order with Benedictine Stability" develops ways both to cope and flourish despite the prevalence of widespread irrationality during the COVID-19 pandemic. Instead of pitting the rational (those who obediently follow stay-at-home orders or mask mandates) against the irrational (those who shun such orders and mandates), Salim seeks an alternative that imbues stay-athome orders with a new, even spiritual, meaning and purpose. Of course, irrationality regarding responses to the pandemic, and conflicts over how to respond to it, abound. Yet the article presents The Rule of St. Benedict's "vow of Stability" as a way to rejuvenate oneself while undergoing unexpected and unprecedented challenges. By developing the core values of the vow of stability (limitations of physical space, overcoming difficulty in institutions, and the action towards the betterment of character in solitude and discipline), we can imagine a way to thrive during "forced" enclosure. Confined physical space and enclosure are essential aspects of the daily life of those Christian monks who engage in study, manual labour, and discipline, and it can bring about simplistic constancy, thankfulness, perseverance, and deeper commitment to one's community.

\section{Section 3: Rethinking Faith and Belonging in the Pandemic}

Then, in our third section of articles, we prolong critiques of irrationality, but pay special attention to the roles our theologies and faith commitments play, and imagine new theological paths forward. Walter Scott Stepanenko's “Ecclesial Belonging in a World of Pure Experience: William James, W. E. B. Du Bois, and Religious Rationality in Crisis" studies the ways in which our present, cultural, modern presumptions about how we "belong" to a Christian community may be more irrational than we tend to realize. Namely, during the COVID-19 pandemic some churches shunned stay-at-home orders and defied State mandates about meeting requirements, and therefore demonstrated a flawed theological understanding of the Church's place in this world. Instead, it is essential to recognize that the church's internal and external practices are sutured to one another, and Stepanenko develops an ideal understanding of ecclesial belonging that does not divorce external from internal activities. Interestingly, the very source of this flawed ecclesiology is not found simply in our theology, but is rather inherited by the very modern, value-neutral skepticism of our "secular institutions" - a skepticism many churches claim to shun. By demonstrating the role of this nonreligious skepticism and an understanding of the rationality that contributed to the epistemic split between internal and external practices, Churches need to reassess their split existence of belonging, both "in" but not "of" the world.

Andrew Oberg's “Enervating the Divine: Seeking New Intuitions about God from a Time of Pandemic" is not focused upon ecclesiology, but rather the doctrine of God and divine action. Oberg demonstrates how our utter lack of control in the COVID-19 crisis creates the opportunity to think relationships anew; namely, between God-world-human and how divine action and human responsibility codetermine one another. By calling into question - along with Keller, Caputo, and others - some traditional theological assumptions, such as God as omnipotent or omniscient, or ex nihilo creation, the article turns to how our "conceptual" understanding determines our "perceptual" lens, which in turn allows us to have a significant and intelligible experience. By reimagining these traditional, theological dogmatic positions, our place in the world, and the way God may be more open and approachable than we usually assume, today we are afforded a new opportunity to relate to one another in this time of crisis. By imagining God otherwise, as having already opened for us a space of interaction, new responsibilities come upon us and new dependencies arise in times of hopelessness. Responsibilities, dependencies, and vulnerabilities furnish us with the opportunity to rethink and discuss with others the personhood of God. 
We are thankful to all the authors for their rich contributions, but also to the many other presenters and keynote speakers (Bruce Benson, Sarah Lane Ritchie, and Tripp Fuller) at the 2020 conference “(Ir)Rationality and Religiosity During Pandemics: Phenomenological Criticism” in which these ideas began to take shape. ${ }^{2}$

2 “(Ir)Rationality and Religiosity During Pandemics: Phenomenological Criticism” took place at the University of Vienna, was supported by the Society for Phenomenology of Religious Experience, and financially made possible through a generous grant by the FWF (Austrian Science Fund) for support of the project "Revenge of the Sacred: Phenomenology and the Ends of Christianity in Europe” (P31919). 